\title{
PERBANDINGAN SELF-REGULATED LEARNING PADA MAHASISWA LAKI-LAKI DAN PEREMPUAN DI JURUSAN BIMBINGAN KONSELING PADA SEMESTER 100 UNIVERSITAS NEGERI JAKARTA
}

\author{
Aditiya Mapanji Wisnuwardana ${ }^{1}$ \\ Sjenny Anggraeni Indrawati, Ed.D. ${ }^{2}$ \\ Dra. Meithy Intan R.L. M.Pd. ${ }^{3}$
}

\begin{abstract}
Abstrak
Perguruan tinggi dapat menjadi waktu penemuan intelektual dan perkembangan diri, khususnya dalam ketrampilan verbal dan kuantitatif, berpikir kritis, dan pemikiran moral. Mahasiswa dituntut untuk lebih mandiri dalam belajar. Tujuan dari penelitia ini adalah untuk melihat Perbandingan Tingkat Self-Regulated Learning Pada Mahasiswa Laki-Laki Dan Perempuan Di Jurusan Bimbingan Konseling Universitas Negeri Jakarta. Penelitian ini dilakukan di jurusan Bimbingan dan Konseling, Fakultas Ilmu Pendidikan, Universitas Negeri Jakarta, Jalan Rawamangun Muka, Jakarta Timur. Metode penelitian yang digunakan adalah metode komparatif dengan pendekatan kuantitatif. Populasi dalam penelitian ini adalah seluruh mahasiswa jurusan Bimbingan dan Konseling Universitas $\mathrm{Ne}$ geri Jakarta yang berjenis kelamin laki-laki dan perempuan yang aktif pada semester 100 tahun pelajaran 2013/2014 yang berjumlah 309 orang, sedangkan pengambilan sampel yang digunakan adalah dengan menggunakan sampel kuota dengan 80 responden, masing-masing 40 untuk tiap jenis kelamin. Berdasarkan hasil perhitungan dengan menggunakan teknik analisis Uji Mann-Whitney U-Test.yang dilakukan dengan aplikasi Statistic Product and Service Solution (SPSS) versi 16.0, diperoleh data Self-Regulated Learning mahasiswa perempuan lebih tinggi dibandingkan dengan Self-Regulated Learning mahasiswa laki-laki $(245.30<261.02)$ dilihat dari Mean. Berdasarkan Levene's test untuk uji homogenitas(perbedaan varians). Tampak bahwa $F=4,304$ ( $p=0,041)$. Karena nilai $t$ ($2,081)$ lebih rendah dibandingkan taraf signifikansi $(0,05)$, maka dapat dapat dikatakan bahwa terdapat perbedaan antara skor Self-Regulated Learning pria dan wanita. Dengan kata lain data Self-Regulated Learning antara mahasiswa laki-laki dan perempuan tidak homogen.
\end{abstract}

Kata Kunci: Self-Regulated Learning, mahasiswa, laki-laki, perempuan

\section{Pendahuluan}

Perguruan tinggi merupakan pendidikan lanjutan setelah Sekolah Menengah Atas (SMA). Mahasiswa mengikuti perkuliahan di perguruan tinggi di- hadapkan pada metode belajar yang diberikan oleh dosen berupa penjelasan mengenai materi, tugas pembuatan makalah dan pemberian tugas kelompok dan tugas yang lain. Papalia pada bukunya yang ber-

\footnotetext{
Mahasiswa Jurusan Bimbingan dan Konseling FIP UNJ, imansetiyantooo@gmail.com

2 Dosen Bimbingan dan Konseling FIP UNJ, shartono@Jisedu.org.id

3 Dosen Bimbingan dan Konseling FIP UNJ, meithy_intan@yahoo.com
} 
judul Human Development, mengatakan : College can be a time of intellectual discovery and personal growth, especially in verbal and quantitive skills, critical thinking, and moral reasoning. Perguruan tinggi dapat menjadi waktu penemuan intelektual dan perkembangan diri, khususnya dalam ketrampilan verbal dan kuantitatif, berpikir kritis, dan pemikiran moral. Mahasiswa dituntut untuk lebih mandiri dalam belajar. Melihat usia mahasiswa yang berada antara 17-25 tahun, maka mereka masuk ke dalam kategori dewasa muda (Young Adulthood) sehingga perkembangan kognitifnya masuk ke dalam Postformal Thought.

Laki-laki cenderung deduktif dalam konseptualisasi mereka, mereka seringkali memulai proses penalaran dari prinsip umum dan mengaplikasikannya, atau dari prinsip pendukung, kemudian ke kasus individual. Mereka juga cenderung melakukan penalaran deduksi lebih cepat dibandingkan perempuan. Ini merupakan alasan bahwa laki-laki, secara rata-rata, lebih baik dan cepat pada tes pilihan ganda, contohnya pada the Scholastic Aptitude Tests. Semakin baik seseorang dalam membuat deduksi secara capat, semakin baik ia dalam mengerjakan tes yang mengandalkan pada keahlian ini. Perempuan di lain pihak cenderung mendukung pemikiran induktif, menambah lebih banyak ke dasar konseptualisasi mereka. Mereka cenderung memulai dengan contoh yang konkrit, lebih mudah mengajarkan mereka hal-hal yang konkrit, khususnya dalam verbalisasi dan menulis."Coba berikan contoh" hal tersebut merupakan tugas yang lebih mudah diminta dilakukan oleh perempuan dibandingkan laki-laki, khususnya pada awal proses konseptualisasi. Lebih sering dibandingkan laki-laki, perempuan mulai dari contoh-contoh spesifik dan kemudian membangun teori umum

Peneliti telah melakukan studi pendahuluan pada mahasiswa BK Non Reg 2009 yang aktif pada semester 100 dengan jumlah mahasiswa laki-laki berjumlah 11 orang dan mahasiswa perempuan berjumlah 27 orang. Studi pendahuluan ini menggunakan sampel satu orang mahasiswa laki-laki dan dua orang mahasiswa perempuan, dikarenakan perbandingan antara laki-laki dan perempuan yang sebesar 1:2. Satu orang mahasiswa laki-laki yang dijadikan responden bernama IS dan dua orang maha- siswa perempuan yang dijadikan responden masingmasing bernama IAT dan MM.

Hasil yang didapatkan dari studi pendahuluan ini adalah terdapat beberapa perbedaan Self-Regulated Learning antara mahasiswa laki-laki dan perempuan. Perbedaan terdapat pada tahap perencanaan atau pengaktifan berpikir rencana ke depan, aspek kognitif di indikator Mengaktifkan kemampuan metakognitif, dan pada aspek Motivasi/Afeksi terdapat perbedaan di indikator Menilai efikasi diri. Perbedaan juga terdapat pada tahap Memonitor, indikator-indikator yang memiliki perbedaan di antaranya Kesadaran metakognisi, Kesadaran dan pemantauan usaha, penggunaan waktu, kebutuhan akan bantuan orang lain, Mengobservasi perilaku diri sendiri (dalam belajar), Memilih dan beradaptasi dengan strategi kognitif untuk proses belajar dan berpikir, Memilih dan beradaptasi dengan strategi untuk mengatur motivasi dan afeksi, Memutuskan untuk menyerah, Mengubah situasi, dan Meninggalkan situasi. Dan pada tahap Refleksi dan Reaksi Diri terdapat perbedaan di indikator-indikator sebagai berikut Atribusi (penghubungan) penilaian kognitif, Pemilihan tingkah laku, Evaluasi dari konteks/situasi

\section{Kajian Teori}

\section{Self-Regulated Learning}

Self-Regulated Learning menurut Boekaerts dapat diartikan sebagai berikut:

Self-regulation refers to self-generated thoughts, feelings, and actions that are and cyclically adapted to the attainment of personal goals.

Sesuai dengan pendapat Boekaerts di atas, maka yang disebut dengan Self-Regulated Learning adalah hasil pemikiran, perasaan dan tindakan diri yang secara terus menerus disesuaikan untuk mencapai tujuan individu. Selain Boekaerts, Heckhaussen juga berpendapat mengenai Self-Regulated Learning :

The mode of volition supporting the maintenance of an active goal is called selfcontrol or action control, whereas the mode supporting the task of maintaining one's actions in line with one's integrated self is called selfregulation. 
Bentuk dari kemauan mendukung pemeliharaan tujuan aktif disebut pengendalian diri atau mengendalikan tindakan, sedangkan bentuk mendukung tugas dari menjaga tindakan seseorang sejalan dengan keterpaduan diri disebut Self-Regulated Learning. Menurut Heckhaussen yang dimaksud dengan Self-Regulated Learning adalah bentuk dorongan perilaku seseorang yang sejalan membentuk integritas dirinya. Menurut Zimmerman, Self-Regulated Learning dalam belajar dapat diartikan sebagai berikut:

In general, students can be described as self-regulated to the degree that they are metacognitively, motivationally, and behaviorally active participants in their own learning process.

Secara umum, para siswa dapat digambarkan mengatur diri pada tingkat metakognitif, motivasi dan partisipasi perilaku aktif dalam proses belajar mereka sendiri. SelfRegulated Learning dalam belajar menurut Zimmerman di atas adalah tingkat peran aktif siswa dalam mengarahkan proses pembelajaran metakognitif, motivasi dan perilakunya.

Metacognitive refers to decision-making processes that regulate the selection and the use of various forms of knowledge.

Tabel Tahapan Self-Regulated Learning dalam Belajar

\begin{tabular}{|c|c|c|c|c|c|}
\hline No & Tahapan & Kognisi & Motivasi/Afeksi & Tingkah Laku & Konteks \\
\hline \multirow{4}{*}{1} & \multirow{4}{*}{\begin{tabular}{|l|} 
Pemikiran \\
Perencanaan, \\
Dan Aktivasi
\end{tabular}} & $\begin{array}{l}\text { Menenetapkan } \\
\text { tujuan sasaran } \\
\text { (belajar). }\end{array}$ & $\begin{array}{l}\text { Mengadopsi } \\
\text { orientasi tujuan. }\end{array}$ & $\begin{array}{l}\text { Merencanakan } \\
\text { waktu dan } \\
\text { usaha }\end{array}$ & $\begin{array}{l}\text { Persepsi } \\
\text { terhadap } \\
\text { tugas }\end{array}$ \\
\hline & & $\begin{array}{l}\text { Mengaktifkan } \\
\text { materi } \\
\text { pengetahuan } \\
\text { sebelumnya }\end{array}$ & Menilai efikasi diri. & \multirow{3}{*}{$\begin{array}{l}\text { Merencanakan } \\
\text { observasi } \\
\text { terhadap } \\
\text { perilaku diri } \\
\text { sendiri }\end{array}$} & \multirow{3}{*}{$\begin{array}{l}\text { Persepsi } \\
\text { terhadap } \\
\text { konteks }\end{array}$} \\
\hline & & \multirow{2}{*}{$\begin{array}{l}\text { Mengaktifkan } \\
\text { pengetahuan } \\
\text { metakognitif }\end{array}$} & $\begin{array}{l}\text { Persepsi tehadap } \\
\text { kesulitan tugas }\end{array}$ & & \\
\hline & & & Aktivasi nilai tugas. & & \\
\hline \multirow[t]{2}{*}{2} & \multirow[t]{2}{*}{ Memonitor } & \multirow[t]{2}{*}{$\begin{array}{l}\text { Kesadaran } \\
\text { metakognisi dan } \\
\text { Memantau } \\
\text { kemampuan } \\
\text { kognitif }\end{array}$} & \multirow[t]{2}{*}{$\begin{array}{l}\text { Kesadaran dan } \\
\text { monitoring } \\
\text { motivasi dan afeksi }\end{array}$} & $\begin{array}{l}\text { Kesadaran dan } \\
\text { pemantauan } \\
\text { usaha, } \\
\text { penggunaan } \\
\text { waktu, } \\
\text { kebutuhan } \\
\text { akan bantuan } \\
\text { orang lain } \\
\end{array}$ & \multirow[t]{2}{*}{$\begin{array}{l}\text { Memantau } \\
\text { pengubahan } \\
\text { tugas dan } \\
\text { kondisi }\end{array}$} \\
\hline & & & & $\begin{array}{l}\text { Mengobservasi } \\
\text { perilaku diri } \\
\text { sendiri (dalam } \\
\text { belajar) }\end{array}$ & \\
\hline \multirow[b]{2}{*}{3} & \multirow[b]{2}{*}{ Kontrol } & \multirow{2}{*}{$\begin{array}{l}\text { Memilih dan } \\
\text { beradaptasi } \\
\text { terhadap } \\
\text { strategi kognitif } \\
\text { untuk proses } \\
\text { belajar dan } \\
\text { berpikir }\end{array}$} & \multirow[b]{2}{*}{$\begin{array}{l}\text { Memilih dan } \\
\text { beradaptasi } \\
\text { terhadap strategi } \\
\text { pengaturan } \\
\text { motivasi dan afeksi. }\end{array}$} & $\begin{array}{l}\text { Meningkatkan } \\
\text { usaha, } \\
\text { Mengurangi } \\
\text { usaha }\end{array}$ & $\begin{array}{l}\text { Mengubah } \\
\text { atau } \\
\text { menegosiasi- } \\
\text { kan kembali } \\
\text { tugas }\end{array}$ \\
\hline & & & & $\begin{array}{l}\text { Melakukan } \\
\text { usaha dengan } \\
\text { tekun atau } \\
\text { memutuskan } \\
\text { untuk } \\
\text { menyerah, } \\
\text { Berusaha } \\
\text { mencari } \\
\text { bantuan }\end{array}$ & $\begin{array}{l}\text { Mengubah } \\
\text { atau } \\
\text { Meninggalkan } \\
\text { situasi. }\end{array}$ \\
\hline \multirow[b]{2}{*}{4} & \multirow{2}{*}{$\begin{array}{l}\text { Reaksi Dan } \\
\text { Refleksi }\end{array}$} & \multirow{2}{*}{$\begin{array}{l}\text { Atribusi } \\
\text { penilaian } \\
\text { kognitif }\end{array}$} & \multirow{2}{*}{$\begin{array}{l}\text { Atribusi reaksi } \\
\text { afeksi }\end{array}$} & \multirow{2}{*}{$\begin{array}{l}\text { Pemilihan } \\
\text { tingkah laku }\end{array}$} & Evaluasi tugas \\
\hline & & & & & $\begin{array}{l}\text { Evaluasi } \\
\text { konteks }\end{array}$ \\
\hline
\end{tabular}

Metakognitif yang dimaksud oleh Zimmerman adalah proses-proses pengambilan keputusan yang mengatur pemilihan dan penggunaan berbagai bentuk pengetahuan.

\section{Pengertian Mahasiswa}

Mahasiswa menurut kamus besar Bahasa Indonesia adalah orang yang belajar di perguruan tinggi, usia mereka berada pada rentangan 18-22 tahun. Definisi tersebut digunakan untuk mahasiswa jenjang S1 sedangkan bagi mahasisawa S2 dan S3 usia mereka dapat melampaui 22 tahun. Menurut Hurlock dalam Santrock pada usia 18 tahun hingga 40 tahun, individu berada pada masa dewasa dini, dengan demikian mahasiswa berada pada tahap perkembangan remaja akhir dan mulai memasuki masa dewasa dini.

Hurlock berpendapat bahwa dari segi tahap perkembangan, rentang usia 18-25 tahun masuk ke dalam masa transisi dari tahap remaja ke dewasa (emerging adulthood) yang penuh perubahan dalam hidup. Memasuki perguruan tinggi setelah lulus dari sekolah menengah merupakan salah satu perubahan yang dialami oleh individu dalam masa emerging adulthood (munculnya kedewasaan). Selain mengalami perbedaan karakteristik belajar dengan sekolah dasar dan menengah, individu juga harus menyesuaikan diri dalam hal peningkatan fokus pencapaian di lingkungan perguruan tinggi.

Setelah melakukan wawancara sederhana dengan 2 orang mahasiswa perempuan dan 1 orang mahasiswa laki-laki pada tanggal 14 dan 17 Maret 2014. mengenai Self-Regulated Learning didapatkan data berupa: Peneliti telah melakukan studi pendahu- 
luan pada mahasiswa BK Non Reg 2009 yang aktif pada semester 100 dengan jumlah mahasiswa lakilaki berjumlah 11 orang dan mahasiswa perempuan berjumlah 27 orang. Studi pendahuluan ini menggunakan sampel satu orang mahasiswa laki-laki dan dua orang mahasiswa perempuan, dikarenakan perbandingan antara laki-laki dan perempuan yang sebesar 1:2. Satu orang mahasiswa laki-laki yang dijadikan responden bernama IS dan dua orang mahasiswa perempuan yang dijadikan responden masing-masing bernama IAT dan MM. Hasil yang didapatkan dari studi pendahuluan ini adalah terdapat beberapa perbedaan Self-Regulated Learning antara mahasiswa laki-laki dan perempuan. Melihat dari tahapan dan indikator Self-Regulated Learning model Pintrich.

Berdasarkan pemaparan tersebut dapat disimpulkan jika mahasiswa laki-laki memiliki keunggulan dalam bidang metakognitif dibandingkan dengan mahasiswa perempuan, Montalvo dan Torres mengatakan,

"For example, those activities related to selfobservation of comprehension (metacognitive awareness) are include here. These activities are manifest when students are aware that they have not understood something they have just read or heard, when they are aware that they are reading too quickly for the type of text involved or for the goals they have set (e.g. understanding the main ideas)".

Sebagai contoh, aktivitas-aktivitas yang berhubungan dengan pemahaman mendalam observasi diri (kesadara metakognisi) termasuk disini. Aktivitas-aktivitas ini dimanifestasikan ketika peserta didik sadar bahwa mereka tidak memahami sesuatu yang mereka baca atau dengar, ketika mereka sadar bahwa mereka membaca terlalu cepat untuk tipe yang melibatkan teks atau untuk tujuan yang telah mereka buat.

Berdasarkan pendapat ini maka hasil studi pendahuluan menunjukan jika responden laki-laki menunjukan kesadaran metakognisi yang lebih baik dibandingkan dengan responden perempuan. Selain itu mahasiswa laki-laki memilih untuk belajar di situasi yang menurutnya nyaman sedangkan mahasiswa perempuan lebih fleksibel dengan tidak memilih tempat ataupun situasi ketika ian belajar. Hal tersebut menjadi kekuatan tersendiri bagi mahasiswa perempuan dalam belajar dilihat dari SelfRegulated Learning. Seperti yang dikatakan oleh Montalvo dan Torres

\section{"Motivation and emotions (motivational strategies and strategies of emotional control), as well as those related to regulating time and effort and to control of diverse academic task, and control of the atmosphere and structure of the class".}

Motivasi dan emosi (strategi-strategi motivasional dan strategi-strategi dari control emosi), dan juga yang lain berkaitan dengan regulasi waktu dan usaha serta kontrol akan beragam tugas akademik, dan kontrol dari atmosfer dan situasi kelas. Berdasarkan pendapat ini berarti mahasiswa perempuan sendiri memiliki keunggulan di tahap motivasi/afeksi, sehingga dapat dikatakan mahasiswa perempuan memiliki usaha yang lebih giat dibandingkan dengan mahasiswa laki-laki dalam hal usaha untuk mengatur atmosfer dan situasi yang mendukung belajar. Hal-hal yang sudah disampaikan ini merupakan hasil dari studi pendahuluan yang sebelumnya telah dilakukan, bukan merupakan keseluruhan perilaku dari setiap mahasiswa Bimbingan dan Konseling di Universitas Negeri Jakarta.

\section{Metodologi Penelitian}

Penelitian ini dilakukan di jurusan Bimbingan dan Konseling, Fakultas Ilmu Pendidikan, Universitas Negeri Jakarta, Jalan Rawamangun Muka, Jakarta Timur pada bulan April sampai Juni 2014. Metode penelitian yang digunakan adalah metode komparatif dengan pendekatan kuantitatif. Populasi dalam penelitian ini adalah seluruh mahasiswa jurusan Bimbingan dan Konseling Universitas Negeri Jakarta yang berjenis kelamin laki-laki dan perempuan yang aktif pada semester 100 tahun pelajaran 2013/2014 yang berjumlah 309 orang, Sedangkan pengambilan sampel yang digunakan adalah dengan menggunakan sampel kuota. Sampel kouta adalah teknik untuk menentukan sampel dari populasi yang mempunyai cirri-ciri tertentu sampai jumlah (kuota) yang diinginkan. Peneliti menentukan kuota dalam penelitian ini sebanyak masing-masing 40 respon- 
den karena menyesuaikan dengan jumlah responden yang tersedia.

Teknik pengumpulan data yang digunakan yaitu menggunakan instrument yang dibuat berdasarkan Self-Regulated Learning model Pintrich. Memiliki 96 butir peryataan yang dibuat sesuai dengan aspekaspek maupupn indikator-indikator dari Self-Regulated Learning model Pintrich.

Uji coba instrumen dalam penelitian ini digunakan pengujian validitas dan reliabilitas menggunakan bantuan Microsoft Excel. Adapun ketentuan pengujian dapat dilihat berdasarkan besarnya $r_{\text {hitung }}$. Apabila $r_{\text {hitung }}$ lebih besar dari $r_{\text {tabel }}$, maka item pernyataan dinyatakan valid, sebaliknya apabila $r_{\text {hitung }}$ lebih kecil dari $r_{\text {tabel }}$ maka item pernyataan dinyatakan tidak valid (drop). Setelah dilakukan uji validitas instrumen, diperoleh hasil bahwa dari 190 butir pernyataan yang diujikan, 96 butir pernyataan dinyatakan valid dan 94 pernyataan lainnya dinyatakan tidak valid (drop). Realibilitas instrumen sebesar 0.9398 yang berarti tinggi, artinya instrumen konsep diri reliabel dan layak digunakan sebagai alat ukur dalam penelitian.

Dalam penelitian ini teknik analisis data dilakukan dengan menggunakan teknik Uji Mann-Whitney U-Test. Teknik ini digunakan untuk menguji signifikansi perbedaan respon dari dua populasi data yang saling independen. Adapun rumus dari independent sample t-test ini sebagai berikut:

$$
U=n_{1} n_{2}+\frac{n_{1}\left(n_{1}+1\right)}{2}-R_{1}
$$

Dengan keterangan :

$\mathrm{U}=$ jumlah peringkat

n_1 = jumlah kelompok 1

n_2 = jumlah kelompok 2

$\mathrm{R} \quad=$ jumlah rangking pada sampel $\mathrm{n}_{-} 1$

Analisis data dilakukan dengan menggunakan SPSS versi 16.00 . Hipotesis dalam penelitian ini diuji pada taraf signifikansi $\alpha=0.05$ atau dengan tingkat kesalahan sebesar 5\%. Setelah perhitungan uji hipotesis dilakukan, maka dapat ditentukan kriteria uji hipotesisnya sebagai berikut;

$$
\mathbf{H}_{0}=\text { nilai asymp.sig }>\text { signifikan } \alpha=0.05
$$

Tidak terdapat perbedaan antara Skor Self-Regulated Learning mahasiswa laki-laki dan skor SelfRegulated Learning mahasiswa perempuan.

$$
H_{1}=\text { nilai asymp.sig }<\text { signifikan } \alpha=0.05
$$

Terdapat perbedaan antara Skor Self-Regulated Learning mahasiswa laki-laki dan skor Self-Regulated Learning mahasiswa perempuan.

\section{Hasil dan Pembahasan}

Berdasarkan hasil pengolahan data terhadap SelfRegulated Learning Mahasiswa Berdasarkan Jenis Kelamin Laki-Laki, diperoleh skor tertinggi sebesar 326 dan skor terendah sebesar 200 dengan skor rata-rata 261,35 dan simpangan baku 37,26. Berdasarkan ketentuan di atas, dapat disimpulkan pada tabel berikut:

Kategori Self-Regulated Learning Mahasiswa Ber-
dasarkan Jenis Kelamin Laki-Laki
\begin{tabular}{|c|c|c|c|}
\hline Rentang & Jumlah & $\%$ & Kategori \\
\hline $200-223$ & 7 & $17.5 \%$ & Rendah \\
\hline $225-261$ & 25 & $62.5 \%$ & Sedang \\
\hline $299-326$ & 8 & $20 \%$ & Tinggi \\
\hline
\end{tabular}

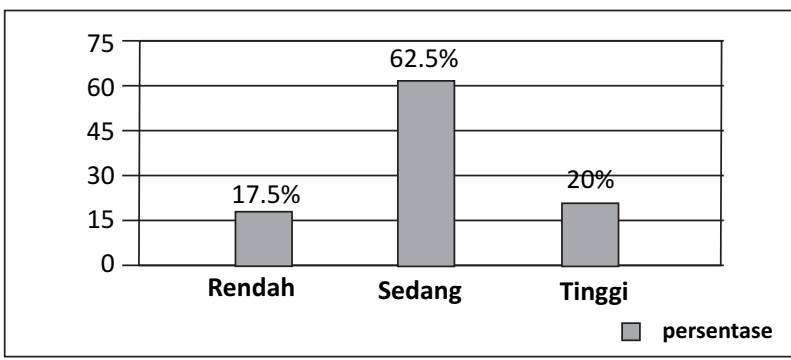

Grafik 4.1 Kategori Self-Regulated Learning Mahasiswa Berdasarkan Jenis Kelamin Laki-Laki

Dengan demikian, disimpulkan bahwa SelfRegulated Learning mahasiswa berdasarkan jenis kelamin laki-laki dapat dikategorikan sedang karena sebesar $62,6 \%$ atau sebanyak 25 orang mahasiswa laki-laki berada pada kategori Self-Regulated Learning sedang.

Berdasarkan hasil pengolahan data terhadap SelfRegulated Learning mahasiswa berdasarkan jenis kelamin perempuan, diperoleh skor tertinggi sebesar 348 dan skor terendah sebesar 180 dengan skor rata-rata 260,48 dan simpangan baku 38,63. 
Kategori Self-Regulated Learning Mahasiswa Berdasarkan Jenis Kelamin Perempuan

\begin{tabular}{|c|c|l|c|}
\hline Rentang & Jumlah & $\%$ & Kategori \\
\hline $180-221$ & 5 & $12.5 \%$ & Rendah \\
\hline $222-299$ & 28 & $70.0 \%$ & Sedang \\
\hline $300-348$ & 7 & $17.5 \%$ & Tinggi \\
\hline
\end{tabular}

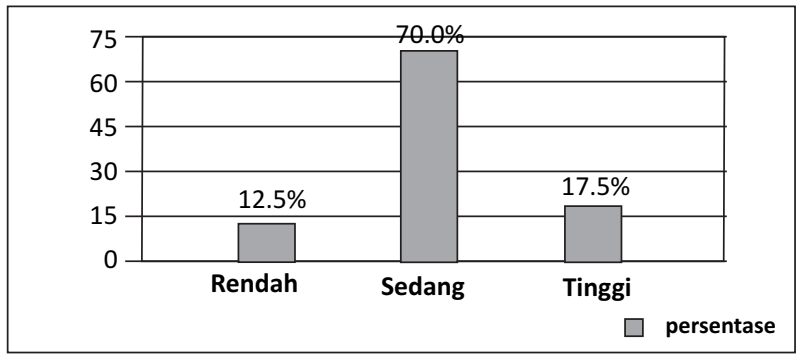

Grafik 4.2 Kategori Self-Regulated Learning Mahasiswa Berdasarkan Jenis Kelamin Perempuan

Dengan demikian, disimpulkan bahwa Self-Regulated Learning mahasiswa berdasarkan jenis kelamin perempuan dapat dikategorikan sedang karena sebesar $70 \%$ atau sebanyak 28 orang mahasiswa perempuan berada pada kategori Self-Regulated Learning sedang.

Berdasarkan hasil perhitungan dengan menggunakan teknik analisis Uji Mann-Whitney U-Test. yang dilakukan dengan aplikasi Statistic Product and Service Solution (SPSS) versi 16.0, diperoleh data sebagai berikut:

Tabel 4.4

Mann-Whitney Test (SPSS 16.00)

Ranks

\begin{tabular}{|cc|c|c|c|}
\hline & VAR00002 & N & Mean Rank & Sum of Ranks \\
\hline VAR00001 & Laki-laki & 40 & 35.99 & 1439.50 \\
& Perempuan & 40 & 45.01 & 1800.50 \\
\hline & Total & 80 & & \\
\hline
\end{tabular}

Pada tabel 4.4 data tersebut menunjukkan bahwa Self-Regulated Learning mahasiswa perempuan lebih tinggi dibandingkan dengan Self-Regulated Learning mahasiswa laki-laki $(245.30<261.02)$ dilihat dari Mean atau rata-rata rangkingnya. 40 orang responden laki-laki rata-rata rangkingnya sebesar 245,30 , sedangkan pada 40 orang responden perempuan rata-rata rangking sebesar 261,02 dan total ranking sebesar 1444,50.

\begin{tabular}{|c|c|}
\hline \multicolumn{2}{|c|}{$\begin{array}{c}\text { Tabel } 4.5 \\
\text { T-Test (SPSS 16.00) } \\
\text { Test Statistics }^{\mathrm{a}} \\
\text { Test Statistics }^{\mathrm{a}}\end{array}$} \\
\hline & VAR00001 \\
\hline Mann-Whitney U & 619.500 \\
\hline Wilcoxon W & 1439.500 \\
\hline Z & -1.737 \\
\hline Asymp. Sig. (2 tailed) & .002 \\
\hline
\end{tabular}

a. Grouping Variable: VAR00002

Berdasarkan Levene's test untuk uji homogenitas (perbedaan varians). Tampak bahwa $\mathrm{F}=4,304$ $(p=0,041)$. Karena nilai Asymp. Sig. (0.002) lebih rendah dibandingkan taraf signifikansi $(0,05)$, maka dapat dapat dikatakan bahwa terdapat perbedaan antara skor Self-Regulated Learning pria dan wanita. Dengan kata lain data Self-Regulated Learning antara mahasiswa laki-laki dan perempuan tidak homogen.

Kemudian dapat dilihat jika nilai nilai Asymp. Sig. (0.002) yang berarti lebih kecil dari nilai signifikansi $\alpha 0.05$. Hal ini membawa pada kesimpulan bahwa $\mathrm{H}_{0}$ ditolak, yaitu terdapat perbedaan yang signifikan Self-Regulated Learning antara mahasiswa laki-laki dan perempuan di Jurusan Bimbingan dan Konseling Universitas Negeri Jakarta.

\section{Kesimpulan dan Saran}

Berdasarkan hasil penelitian mengenai perbedaan perbedaan antara Self-Regulated Learning antara mahasiswa laki-laki dan perempuan di Jurusan Bimbingan dan Konseling Universitas Negeri Jakarta yang telah dipaparkan sebelumnya, maka dapat disimpulkan bahwa:

1. Berdasarkan hasil pengujian hipotesis dengan menggunakan teknik $\mathrm{T}$ - Test, diperoleh nilai $\mathrm{t}$ sebesar -2,081 yang berarti lebih kecil dari nilai signifikansi $\alpha 0.05$. hal ini membawa pada kesimpulan bahwa H0 ditolak, yaitu terdapat perbedaan yang signifikan antara Self-Regulated Learning antara mahasiswa laki-laki dan perempuan di Jurusan Bimbingan dan Konseling Universitas Negeri Jakarta. 